\title{
Seismic Assessment and Rehabilitation of a RC Structure Under Mainshock-Aftershock Seismic Sequences Using Beam-Column Bonded CFRP Strategy
}

Omid Karimzade Soureshjani

Kharazmi University

Gholamreza Nouri ( $\nabla$ r.nouri@khu.ac.ir)

Kharazmi University Faculty of Engineering https://orcid.org/0000-0002-2936-599X

\section{Research Article}

Keywords: Seismic rehabilitation, Beam-column bonded strategy, CFRP, Mainshock-aftershock, Seismic sequences, Nonlinear time-history analysis

Posted Date: November 2nd, 2021

DOI: https://doi.org/10.21203/rs.3.rs-1026929/v1

License: (c) (1) This work is licensed under a Creative Commons Attribution 4.0 International License. Read Full License

Version of Record: A version of this preprint was published at Bulletin of Earthquake Engineering on March 29th, 2022. See the published version at https://doi.org/10.1007/s10518-022-01382-3. 


\title{
Seismic assessment and rehabilitation of a RC structure under mainshock- aftershock seismic sequences using beam-column bonded CFRP strategy
}

\author{
Omid Karimzade Soureshjani, Ph.D. Candidate of Structural Engineering, Kharazmi University \\ Postal address: Kharazmi University, No.43, Dr. Mofatteh Ave., Tehran, IRAN \\ ORCID iD: https://orcid.org/0000-0003-4310-0194 \\ Gholamreza Nouri, Ph.D. Asst. professor of Structural Engineering, Kharazmi University \\ Postal address: Kharazmi University, No.43, Dr. Mofatteh Ave., Tehran, IRAN \\ ORCID iD: https://orcid.org/0000-0002-2936-599X \\ Corresponding author: Gholamreza Nouri \\ Email address: r.nouri@khu.ac.ir, Telephone: +98 2188830891
}

\begin{abstract}
A mainshock is usually accompanied by a group of ground motions. In many design codes, the effects of the seismic sequences have been neglected or underestimated. Aftershocks can increase structural damage or even cause failure. The current study evaluated the seismic behavior of a rehabilitated and as-built RC structure under real scaled mainshock-aftershocks using nonlinear analysis. Verification was done in two modes. The inter-story drift ratio, maximum residual, and relative displacements were studied. The seismic study of the as-built structure showed that the residual displacement grew, on average, more than $90 \%$ under the mainshock-aftershock sequence compared to the mainshock-only record. A beam-column bonded CFRP rehabilitation strategy using six layers of T-700 CFRP was chosen based on the specific performance level. The strategy showed the ability to transfer the plastic strain from the columns to the beams, which could be considered as a change from a weak column-strong beam concept to a strong column-weak beam concept. Compared to the as-built structure under the seismic sequences, the rehabilitated structure showed an average growth of $78 \%$ in the first-story drift ratio, which was significant. Unlike the as-built structure, seismic sequences caused no growth drift in the rehabilitated structure. It also was observed that the ratio of aftershock PGA to mainshock PGA could have an intensive effect on the seismic behavior of both rehabilitated and as-built structures.

Keywords: Seismic rehabilitation, Beam-column bonded strategy, CFRP, Mainshock-aftershock, Seismic sequences, Nonlinear time-history analysis.
\end{abstract}




\section{Introduction}

The strain energy stored in active fault systems is not completely released with a single rupture. In many cases, the strain energy remaining in the fault system could cause repetitive ground motions (aftershocks) at brief intervals (Hatzivassiliou and Hatzigeorgiou, 2015; Amadio et al., 2003). Aftershocks can increase structural damage or even cause building collapse (García and Negrete-Manriquez, 2011). However, in many structural seismic design codes, the ground motions are considered as a single event and the effect of the aftershocks is underestimated (Moustafa and Takewaki, 2011).

When considering the effect of aftershocks (seismic sequences) in seismic areas, a multi-level design approach for the design of structures has been suggested by Di Sarno (2013). Their study investigated the effect of seismic sequences on the inelastic behavior of a reinforced concrete $(\mathrm{RC})$ frame. The results showed that the seismic sequences could be affect the behavior of the RC frame. Li et. al (2014) studied the collapse probability of steel buildings under mainshock-aftershock records, the effect of fault types, and some features of the mainshock-aftershock records. They reported that aftershocks could have a higher peak ground acceleration (PGA), energy content, and even longer duration than the corresponding mainshocks. The study also found that, during a strong mainshock, the collapse capacity of a structure could strongly decrease, meaning that structural collapse would be likely under even a weak aftershock.

Ruiz-García (2012) assessed the characteristics of mainshock-aftershock ground motions by considering 184 real seismic sequences. The effects of real mainshock-aftershocks on the seismic responses of buildings was investigated. The study found that the predominant period of the mainshock was longer than the corresponding aftershock. Furthermore, the seismic behavior of the structures under real seismic sequences was completely different from that under artificial seismic sequences.

Ji et al. (2020) introduced the $\lambda$-index, which is defined as the ratio of the maximum structural residual displacement under a mainshock to the structural damage under an aftershock. This study performed nonlinear seismic analysis using more than 200 seismic sequences and a single degree of freedom (SDOF) model to determine the $\lambda$ index. They proposed an equation for this index to predict structural damage under seismic sequences. Massumi et al. (2021) studied the effect of sequential ground motions (mainshock-aftershock) considering both vertical and horizontal components of two RC moment-resisting structures. The increase of the probability of failure or damage was presented in this study. 
In many seismic design codes, chiefly in regions with modest seismicity, such as central Europe, earthquake hazards have been downgraded (Dazio and Bachmann, 2000). Observation of the effect of strong ground motions such as in Kobe, Japan (1995) and Northridge, CA (1994) on structures which were designed according to the available seismic design codes have led to basic revisions in seismic design provisions (Venture, 2000). It has been recommended to upgrade the seismic performance of existing structures designed according to previous seismic design codes using a new generation of design codes using reliable methods such as rehabilitation strategies (Meitz, 1998).

Considering the trade-off between required strength, cost, application ease, weight reduction, and corrosion resistance, rehabilitation using FRP is an ideal strategy (Hassan and Rizkalla, 2002; Chajlani and Hussain, 2015). Seismic rehabilitation of beam-column joints using FRP laminates was investigated by Ghobarah and Said (2001). Their experimental study contained a full-scaled RC moment-resisting frame tested under cyclic loading. The results showed that the FRP laminates increased the shear capacity and that flexural hinges formed in the beam connections.

Wang et al. (2016) studied the flexural behavior of 16 members filled with CFRP. The results showed that the stiffness and moment capacity of the models improved remarkably. CFRP and steel core corporate with each other perfectly in both transverse and longitudinal directions. The authors presented an equation to calculate the flexural capacity of these kinds of members. Cabral-Fonseca et al. (2018) investigated the durability of concrete joints bonded with FRP sheets. The seismic behavior of six RC columns was investigated and compared with five columns strengthened with FRP sheets in the body and anchors. The moment capacity of the strengthened columns showed remarkable improvement (Del Rey Castillo et al., 2018). The rehabilitation of existing RC structures using FRP sheets and wood and the strengthening of wooden beams using CFRP laminates were studied by Grazide et al. (2020) and İşleyen et al. (2021), respectively. Both studies experimentally and numerically showed that the initial stiffness and ultimate loading capacity improved with the use of FRP or CFRP laminates.

In previous studies on seismic rehabilitation using CFPR or FRP laminates, most attention has been paid to the structural members (beam or column), connections (beam-column) and SDOF models. The effect of seismic sequences, which are probable events in seismic zones, has not been considered or has been neglected. There also has been a lack of seismic rehabilitation studies on multi-story structures and seismic sequences.

The focus of the current study was the rehabilitation and seismic behavior of a multi-story RC structure under seismic sequences. This study investigates the effect of the seismic sequences on an RC structure and proposes a rehabilitation strategy (beam-column bonded CFRP) according to the specific performance level. The sufficiency of 
the proposed rehabilitation strategy also has been assessed. The seismic behavior of the rehabilitated structure also was compared with an as-built structure under seismic sequences to determine whether or not the performance of a rehabilitated structure under a mainshock-aftershock sequence is similar to that under the mainshock.

The effect of the seismic sequences in rehabilitated structures either has been neglected or underestimated by the engineering community and seismic design codes. This study provides a good perspective for the investigation of the seismic performance and sufficiency of rehabilitated RC structures using CFRP under seismic sequences.

\section{Analyzed frame}

The target structural model was the frame of a 6-story RC moment-resisting structure. The model was designed according to an outdated Italian provision that does not contain a seismic design code (Regio Decreto Leggne, 1939). Fig. 1 shows that the frame model has three bays with lengths of $4.5 \mathrm{~m}, 2 \mathrm{~m}$ and $4.5 \mathrm{~m}$. The frame comprises three types of columns and one type of beam in both the short and tall models. The story height was $2.75 \mathrm{~m}$ in the first story and $3 \mathrm{~m}$ in the other stories (Calvi et al., 2002). The compressive strength of the concrete and yield strength of the steel longitudinal and shear rebars were $20 \mathrm{MPa}$ and $380 \mathrm{MPa}$, respectively. The loads applied to the frames during analysis included the frame self-weight, live load, and earthquake forces.
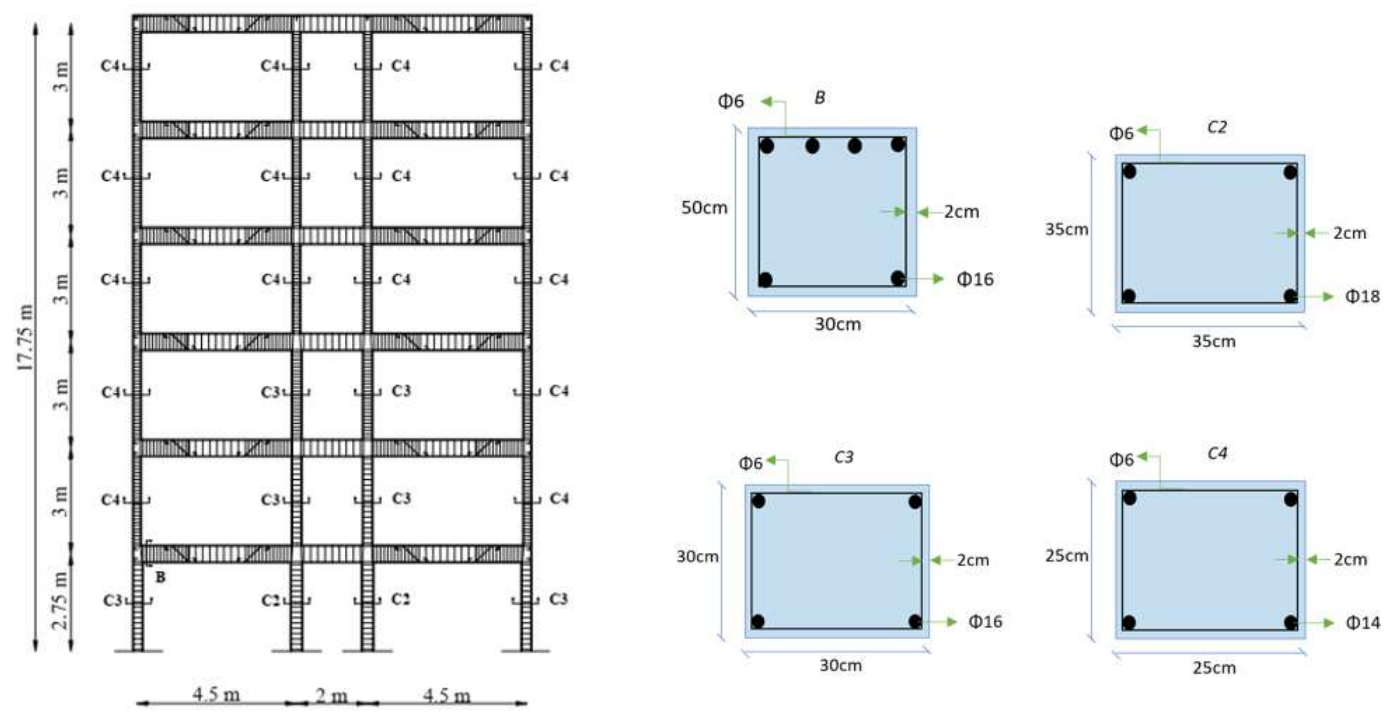

Fig. 1. Details of the studied model

\section{Numerical modeling}

\subsection{Behavior model for concrete}

The compressive behavior of the concrete was calculated using the Mander concrete stress-strain relation in Eqs. (1) to (3) (Mander et al., 1988). The tensile stress-strain curve was defined according to the model of Carreira and Chu 
(1986). In this case, the yield stress was set at $7.5 \sqrt{f^{\prime}}{ }_{c}$ psi where $E$ is the modulus of elasticity, $f^{\prime}{ }_{c}$ is the concrete compressive strength, $\varepsilon^{\prime}{ }_{c}$ is the concrete strain at $f^{\prime}{ }_{c}$ and $\varepsilon$ is the concrete strain.

$$
\begin{gathered}
f=\frac{f^{\prime}{ }_{c} X r}{r-1+X^{r}} \\
X=\frac{\varepsilon}{\varepsilon^{\prime}{ }_{c}} \\
r=\frac{E}{E-\left(\frac{f^{\prime}{ }^{\prime}{ }_{c}}{c}\right)}
\end{gathered}
$$

\subsection{Steel rebar behavior model}

The engineering stress-strain behavior of the rebars was calculated (Eqs. (4) to (6)) using the Ramberg and Osgood (1943) model. This behavior model can be used to approximate the stress-strain curve of material if the yield strength, ultimate strength, elastic modulus, and rupture strain are known. All of these values were readily available in this study. In order to consider the change in the cross-section area and provide a more accurate behavior model for steel rebars under loading, the true stress-strain curve was calculated using the engineering curve and Eqs. (7) and (8) (Beer et al., 2013), where $f_{u}$ and $f_{y}$ are the ultimate and yield strengths, respectively, $\sigma$ is the stress, $\varepsilon$ is the strain, $\varepsilon_{r}$ is the rupture strain, $n$ is the material-dependent constant, $\sigma_{\text {true }}$ and $\varepsilon_{\text {true }}$ are the true stress and strain, respectively.

$$
\begin{gathered}
\varepsilon=\frac{\sigma}{E}+0.002\left(\frac{\sigma}{E}\right)^{n} \\
n=\frac{\operatorname{Ln}\left(\frac{\varepsilon_{u s}}{0.2}\right)}{\operatorname{Ln}\left(\frac{f_{u}}{f_{y}}\right)} \\
\varepsilon_{u s}=100 *\left(\varepsilon_{r}-\frac{f_{u}}{E}\right) \\
\sigma_{\text {true }}=\sigma *(1+\varepsilon) \\
\varepsilon_{\text {true }}=\operatorname{Ln}(1+\varepsilon)
\end{gathered}
$$

\section{Finite element implementation}

The proposed structure was modeled in ABAQUS software. The concrete damage plasticity model was used to define the concrete behavior. This model is based on the assumption of isotropic damage and is an analytical model used for the analysis of materials with concrete-like properties and behavior in which the intended material is subject to 
arbitrary loads, such as cyclic loads (Dassault Systèmes, 2017). This model has the ability to consider the interaction between the rebars and concrete (as in RC structures). Nonlinear implicit time-history analysis was employed based on the unconditionally stable Hilber Hughes Taylor (HHT) method, with appropriate time increments and a full Newton-Raphson solution (Dassault Systèmes, 2017; Hilber et al., 1977; Hibbitt and Karlsson, 1979).

Figs. 2(a) and 2(b) show the finite element (FE) frame. For accurate analysis, the FE model was modeled in detail (section 2). The mesh elements of 8-node linear brick, 2-node linear 3D trusses, and 4-node doubly curved thin shells of appropriate sizes were assigned for the concrete, steel rebars, and CFRP materials, respectively (Johnson, 2006).

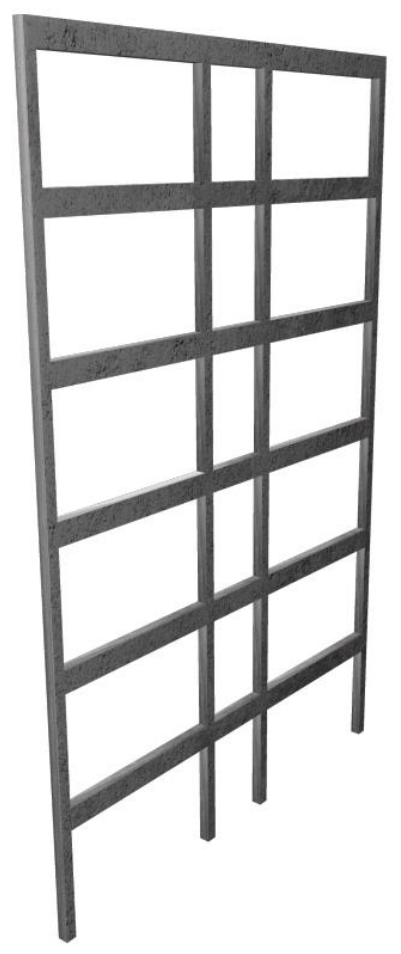

(a)

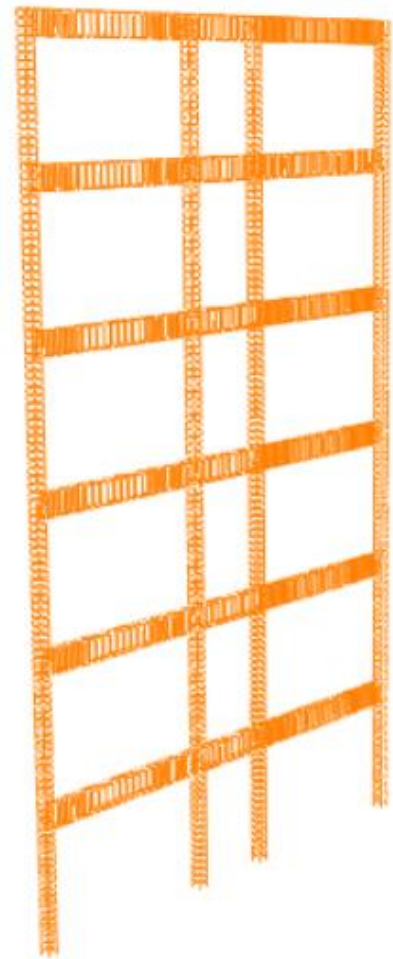

(b)

Fig. 2. 3D view of the FE model: (a) whole model (b) reinforcement

\section{Verification}

\subsection{CFRP behavior model}

To investigate the accuracy of CFRP modeling, the capacity of a beam rehabilitated using CFRP sheets (experimental model) was compared with the results of the FE model. The proposed beam model has been experimentally tested by Ahmadi (2013). The beam was a rectangular RC beam with a total length of $1.1 \mathrm{~m}$, depth of $0.4 \mathrm{~m}$, and width of 0.05 
$\mathrm{m}$. The concrete was M30 with a yield strength of $335 \mathrm{MPa}$. Support plates were placed at each end of the beam and the effective length of the beam was $0.8 \mathrm{~mm}$. Figs. 3(a) and 3(b) show the geometry of the beam model.
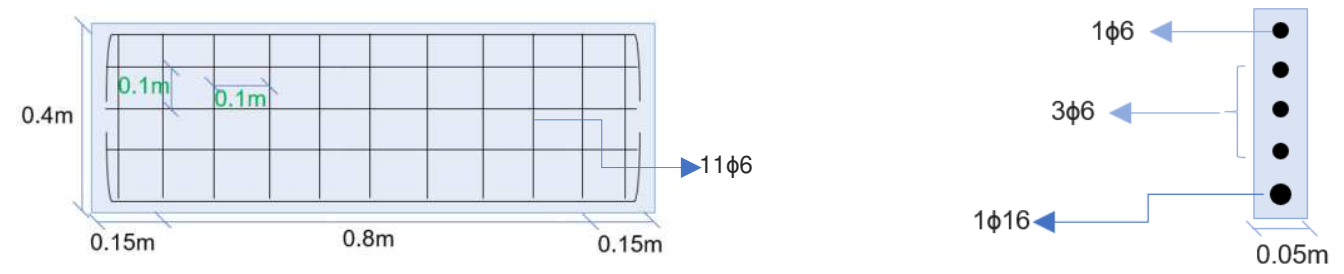

(a)

Fig. 3. The beam model scheme: (a) the geometry and details (b) elevation view

The shear failure mode was considered as the dominant failure mode and the shear cracks expand at $45^{\circ}$ (Parry, 2004). An orthogonal pattern was used for the CFRP at a $45^{\circ}$ angle to the horizon. The FE models of the proposed beam model in both unrehabilitated and rehabilitated states are shown in Figs. 4(a) and 4(b), respectively. The total number of mesh elements were 1703 and 19421 for the unrehabilitated and rehabilitated models, respectively. The CFRP sheets were applied to both sides of the rehabilitated beam.

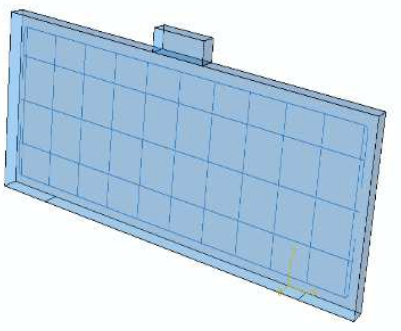

(a)

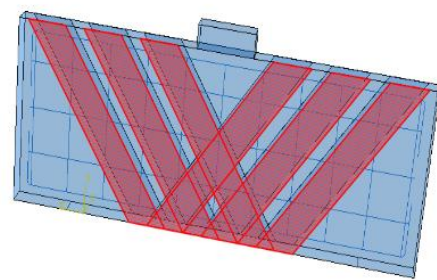

(b)

Fig. 4. FE model of the beam: (a) un-rehabilitated (b) rehabilitated

The capacity curves of the models were obtained by applying a concentrated load at the mid-span of the beam and increasing it monotonically. Fig. 5 shows the capacity curves (load-displacement) of the experimental and FE models. The areas under capacity curves (absorbed energy) were calculated and compared. The unrehabilitated and rehabilitated FE models showed a difference of $4.48 \%$, and $1.86 \%$ compared to the corresponding experimental models. This indicates that there was good agreement between the experimental and FE models. 


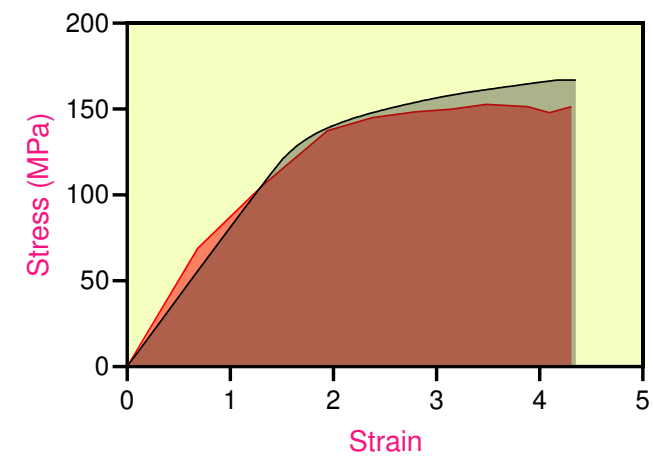

(a)

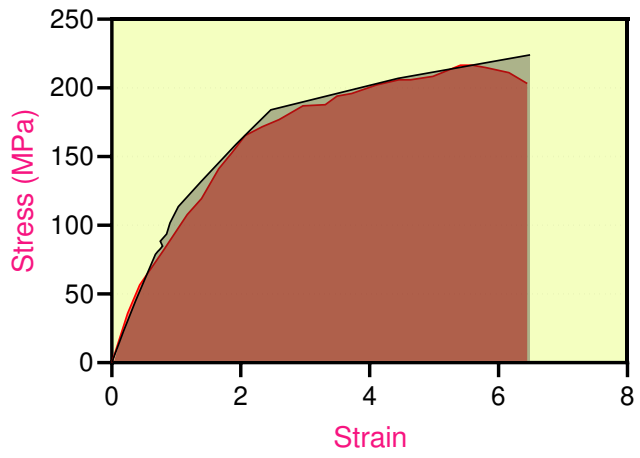

(b)

FE model (this study)

Experimental model

Fig. 5. Capacity curves: (a) un-rehabilitated (b) rehabilitated

\subsection{Seismic analysis}

To verify the nonlinear behavior of the structural model, it was analyzed under the Loma Prieta (1989) ground motion using time-history analysis (Table 1). In this regard, the maximum relative displacement of the FE model was compared with the results of the Calvi et al. (2002) for the same record. Fig. 6 shows that there was good agreement between diagrams on the both the negative and positive sides.

Table 1. Details of the Loma Prieta ground motion

\begin{tabular}{|c|c|c|c|}
\hline Event & Station & Year & Magnitude $\left(\mathrm{M}_{\mathrm{w}}\right)$ \\
\hline Loma Prieta & Hollister Differential Array & 1989 & 6.9 \\
\hline
\end{tabular}

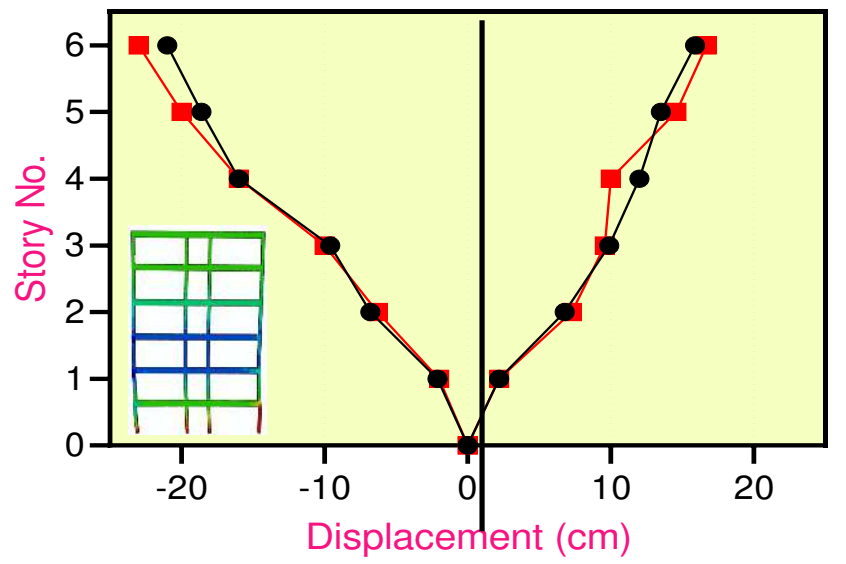

FE model (this study) Calvi, G. M. et al. (2002)

Fig. 6. Comparison of maximum relative displacement

\section{Mainshock-aftershock records}

Seven real scaled mainshock-aftershock ground motion records were chosen to investigate the effect of seismic sequences on the rehabilitated and as-built frames (Ruiz-Garcia, 2012; Pacific Earthquake Engineering Research 
Centre, 2011; Wang et al., 2018). The aftershocks (seismic sequences) were selected using the seismic declustering method using space-time history (Hainzl et al., 2010). For comprehensive and accurate analysis, seismic sequences with different ranges of magnitude, PGA values and aftershock PGA to mainshock PGA ratios were chosen. Table 2 and Fig.7 show the details and time history records of the intended ground motions, respectively. For purposes of reasonable comparison, the PGAs of the mainshocks were scaled to $0.4 \mathrm{~g}\left(3.92 \mathrm{~m} / \mathrm{s}^{2}\right)$. The aftershocks were adjusted using their corresponding mainshock PGA scale coefficient. The acceleration time-history records of seismic sequences for the Kozani, Mammoth Lakes, Cape Mendocino, Imperial Valley, Whittier Narrows, Northridge, and Coalinga records were multiplied by coefficients of $1.96,0.94,0.60,1.22,0.93,0.46$, and 3.29 , respectively. A fivesecond interval with zero acceleration between the mainshock and aftershock records was testing using trial and error to ensure that the structure did not vibrate.

Table 2. Details of the mainshock-aftershock ground motions

\begin{tabular}{|c|c|c|c|c|}
\hline Event & Station & Year & Type & Magnitude $\left(\mathbf{M}_{\mathbf{w}}\right)$ \\
\hline \multirow{2}{*}{ Kozani } & \multirow{2}{*}{ Kozani } & \multirow{2}{*}{1995} & Mainshock & 6.40 \\
\hline & & & Aftershock & 5.30 \\
\hline \multirow{2}{*}{ Mammoth Lakes } & \multirow{2}{*}{ Convict Creek } & \multirow{2}{*}{1980} & Mainshock & 6.06 \\
\hline & & & Aftershock & 5.70 \\
\hline \multirow{2}{*}{ Cape Mendocino } & \multirow{2}{*}{ Petrolia } & \multirow{2}{*}{1992} & Mainshock & 7.01 \\
\hline & & & Aftershock & 6.60 \\
\hline \multirow{2}{*}{ Imperial Valley } & \multirow{2}{*}{ El Centro Array \#4 } & \multirow{2}{*}{1979} & Mainshock & 6.53 \\
\hline & & & Aftershock & 5.01 \\
\hline \multirow{2}{*}{ Whittier Narrows } & \multirow{2}{*}{ LA-Obregon Park } & \multirow{2}{*}{1987} & Mainshock & 5.99 \\
\hline & & & Aftershock & 5.27 \\
\hline \multirow{2}{*}{ Northridge } & \multirow{2}{*}{ Rinaldi } & \multirow{2}{*}{1994} & Mainshock & 6.69 \\
\hline & & & Aftershock & 5.28 \\
\hline \multirow{2}{*}{ Coalinga } & \multirow{2}{*}{ Coalinga-14th } & \multirow{2}{*}{1983} & Mainshock & 5.09 \\
\hline & & & Aftershock & 4.89 \\
\hline
\end{tabular}




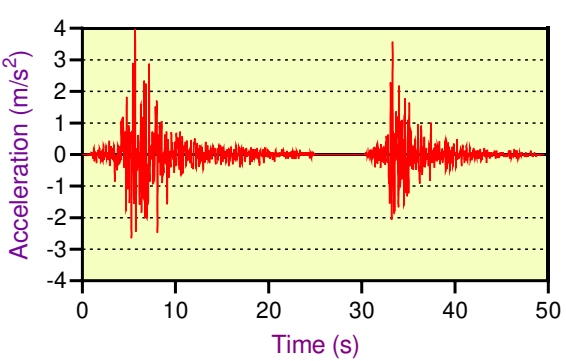

(a)

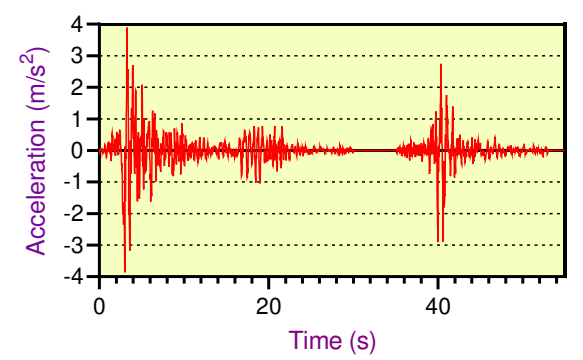

(c)

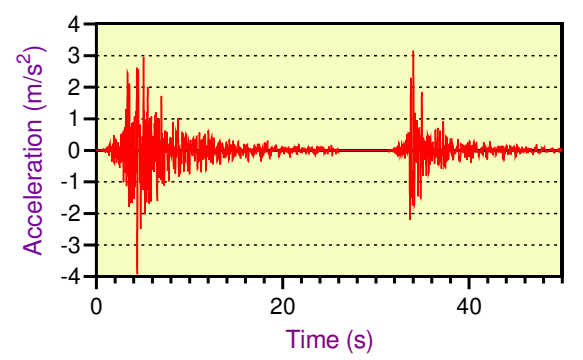

(e)

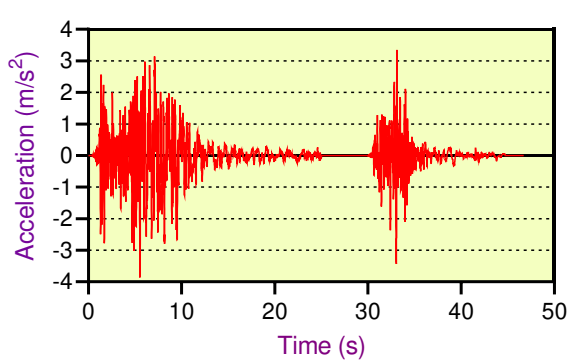

(b)

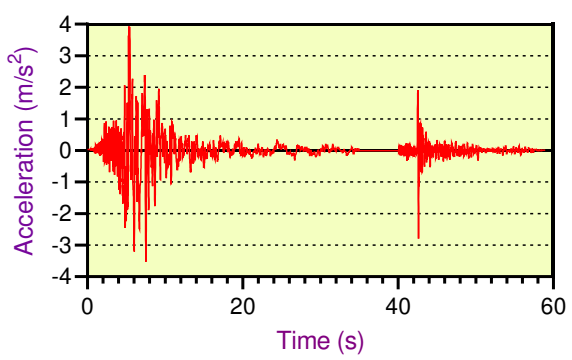

(d)

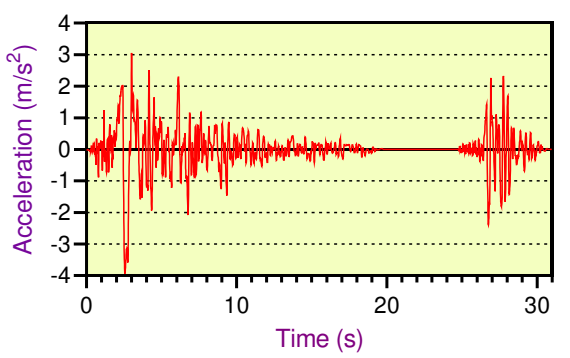

(f)

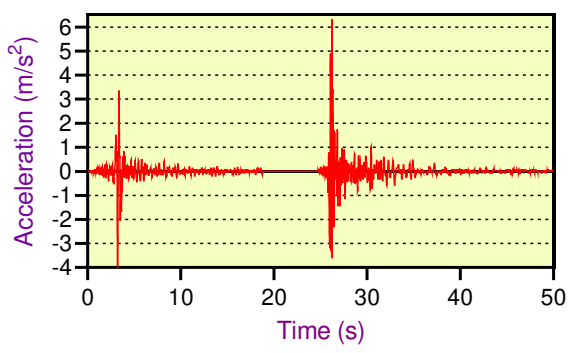

(g)

Fig. 7. Scaled mainshock-aftershock acceleration records: (a) Kozani (b) Mammoth Lakes (c) Cape Mendocino (d) Imperial Valley (e) Whittier Narrows (f) Northridge (g) Coalinga

\section{Numerical investigation and discussion}

\subsection{Seismic behavior of as-built structure}


The top story displacement of the as-built structure under the mainshocks (section 6) was recorded. On average, aftershocks caused a $92.8 \%$ growth in the residual displacement compared to the mainshock only, which is remarkable. This means that the aftershocks caused almost as much of an increase in the residual displacement as did the mainshocks. For example, under the Cape Mendocino seismic sequence, the residual displacement increased from 9.1 $\mathrm{cm}$ for the mainshock alone to $18.5 \mathrm{~cm}$ for the mainshock-aftershock. Structural damage caused by the mainshock affected the growth of residual displacement under the aftershocks. This indicates that the consideration of seismic sequences for this type of structure could be vital.

The drift ratio is a fundamental structural parameter used for the seismic assessment of a structure (Yang et al., 2010). The drift ratio of the as-built structures under the mainshock and mainshock-aftershock ground motions (section 6) were calculated and are shown in Fig. 8. Table 3 presents some seismic data about the as-built structure.

Table 3. Seismic behavior data of the as-built structure under seismic sequences

\begin{tabular}{|c|c|c|c|c|c|c|}
\hline 1 & 2 & 3 & 4 & 5 & 6 & 7 \\
\hline Event & $\begin{array}{l}\text { Top story relative } \\
\text { displacement } \\
\text { under Mainshock } \\
\qquad(\mathrm{cm})\end{array}$ & $\begin{array}{l}\text { Top story relative } \\
\text { displacement under } \\
\text { Mainshock- } \\
\text { aftershock }(\mathrm{cm})\end{array}$ & $\begin{array}{l}\text { Growth of } 3 \\
\text { compared to } \\
\qquad 2^{\wedge}(\%)\end{array}$ & $\begin{array}{l}\text { Mainshock- } \\
\text { aftershock top } \\
\text { drift ratio }(\%)\end{array}$ & $\begin{array}{l}\text { Story with } \\
\text { the most } \\
\text { drift ratio* }\end{array}$ & $\begin{array}{l}\text { Drift ratio } \\
\text { growth }^{\bullet}(\%)\end{array}$ \\
\hline Kozani & 28.1 & 35.1 & 24.99 & 1.97 & 1 & 10.19 \\
\hline Mammoth Lakes & 27.0 & 27.2 & 0 & 1.52 & 1 & 20.11 \\
\hline Cape Mendocino & 23.3 & 25.6 & 8.66 & 1.40 & 1 & 17.30 \\
\hline Imperial Valley & 20.1 & 20.2 & 0 & 1.12 & 1 & 0 \\
\hline Whittier Narrows & 28.4 & 28.7 & 0 & 1.57 & 1 & 38.46 \\
\hline Northridge & 22.2 & 25.4 & 13.63 & 1.40 & 1 & 15.77 \\
\hline Coalinga & 26.7 & 48.2 & 84.61 & 2.70 & 1 & 43.60 \\
\hline
\end{tabular}

$\Delta$ Growth $=\frac{\operatorname{column}(3)-\operatorname{column}(2)}{\operatorname{column}(2)} *$ Story with the most drift ratio under mainshock. $\bullet$ Drift ratio growth $(\%)$, showing the growth of the story with the most drift ratio under mainshock-aftershock (column 6), compared to drift ratio of the same story considering solely the mainshock 


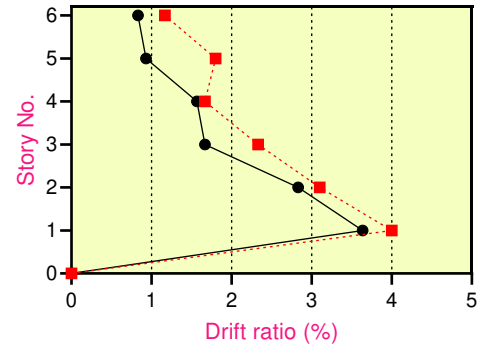

(a)

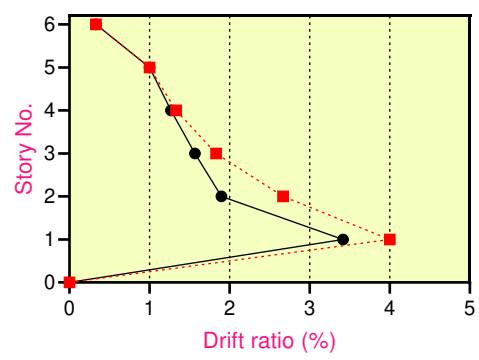

(c)

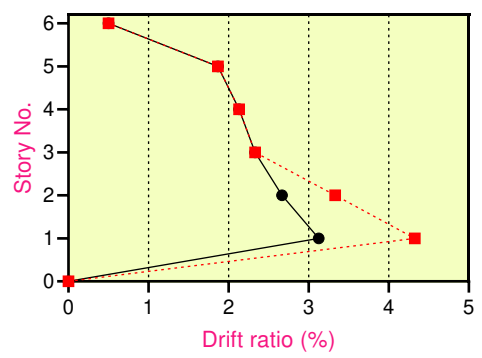

(e)

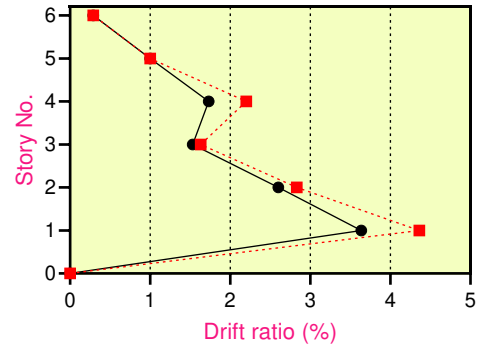

(b)

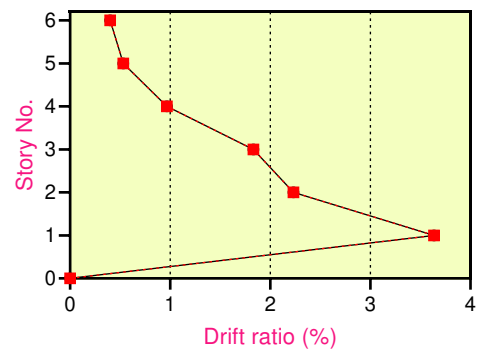

(d)

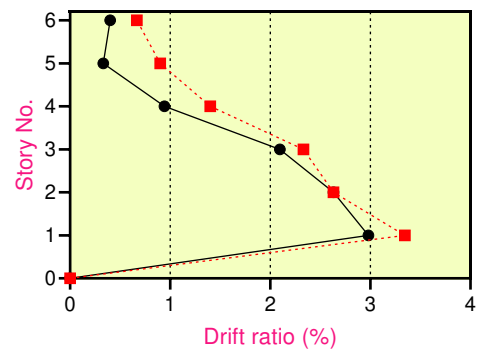

(f)

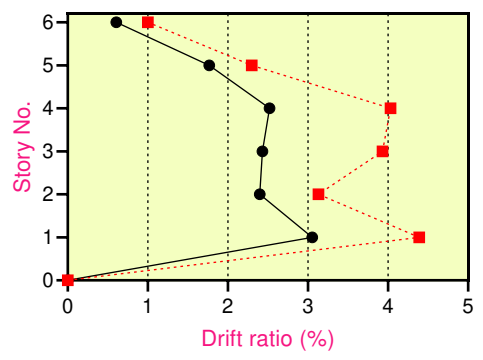

(g)

Mainshock Mainshock-aftershock

Fig. 8. Mainshock and mainshock-aftershock drift ratio: (a) Kozani (b) Mammoth Lakes (c) Cape Mendocino (d) Imperial Valley (e) Whittier Narrows (f) Northridge (g) Coalinga

Table 3 and Fig. 8 indicate that the aftershocks primarily increased the drift ratio in the lower stories. The highest drift ratios occurred in stories 1, 2, and 3, respectively. These stories experienced the most damage (plastic strain) under the mainshock, but the aftershocks caused a dramatic increase in the drift ratio in these stories. On the contrary, 
in stories 5 and 6 , the seismic sequences caused no remarkable increase in drift ratios because there was very little damage, plastic strain, or complete elastic behavior under the mainshock. Stories 5 and 6 under the Northridge mainshock, for example, showed no remarkable drift ratio growth).

In the FEMA pre-standard and commentary for the seismic rehabilitation of buildings, a drift ratio of $2 \%$ is considered to be the life safety limit (LS) for concrete frames (Federal Emergency Management Agency, 2000). As is clear in Fig. 8, the structure experienced drift ratios of more than 2\% (3.33\% on average in the first story) under all mainshocks in the lower floors. These high drift ratios could cause structural instability; therefore, a rehabilitation strategy was chosen and was assessed (section 7.2). The maximum and minimum ranges and average drift ratios under the mainshock and mainshock-aftershock records are shown in Fig. 9.

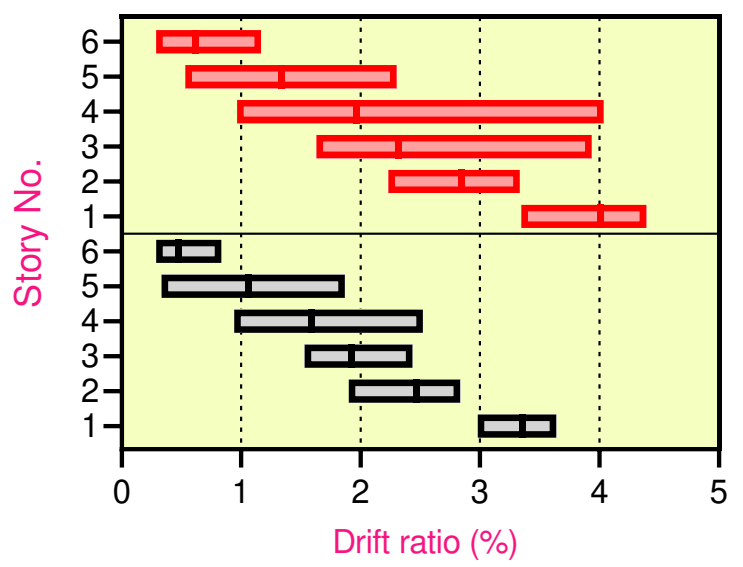

Mainshock Mainshock-aftershock

Fig. 9. Maximum, minimum ranges, and average value of drift ratios

\subsection{Seismic rehabilitation strategy}

An effective seismic rehabilitation strategy should decrease the undesirable effect of seismic loading and improve the seismic performance in a structure in accordance with its performance level (limit state). For each case, several efficient strategies can be suggested, each having advantages and disadvantages. These include steel/concrete shear walls, infill concrete panels, steel bracing, active and passive structural control systems, and FRPs (El-Sokkary and Galal, 2009; Kurata et al., 2012; Hollaway, 2014; Ghobarah, Abou Elfath, 2001; Syrmakezis et al., 2006).

Fig. 10 shows the plastic strain magnitude of a structure under the Imperial valley mainshock-aftershock. Plastic behavior formed predominantly in the columns and beam-column connections, which represents the weak column- 
strong beam concept (Ye et al., 2010). This concept relates to the type of structural design in which the model experiences high drift, chiefly in the lower floors under lateral loading (section 7.1). In this case, the seismic rehabilitation of the structure was done using the beam-column bonded T700-CFRP sheet strategy. This strategy can transfer the plastic strain from the columns to the beams (strong column-weak beam concept), which sharply decreased the drift ratio under seismic or lateral loading. Table 4 shows the mechanical properties of the T700-CFRP sheets (Hassan et al., 2018; Toray Composite Materials America Inc., 2020). T700 CFRP sheets are generally used to increase the load-carrying capacity and stiffness of building, bridges, silos, chimneys, and similar structures (Toray Composite Materials America Inc., 2020).

Table 4. T700-CFRP mechanical property

\begin{tabular}{|c|c|}
\hline Mechanical property & Value \\
\hline Thickness & $1.02 \mathrm{~mm}$ \\
\hline Density & $1800 \mathrm{~kg} / \mathrm{m}^{3}$ \\
\hline Filament Diameter & $7 \mu \mathrm{m}$ \\
\hline $\mathbf{E}_{\mathbf{x}}$ & $132 \mathrm{GPa}$ \\
\hline $\mathbf{E}_{\mathbf{y}}$ & $10.3 \mathrm{GPa}$ \\
\hline $\mathbf{E}_{\mathbf{z}}$ & $10.3 \mathrm{GPa}$ \\
\hline $\mathbf{v}_{\mathbf{x y}}$ & \\
\hline $\mathbf{v}_{\mathbf{y z}}$ & 0.25 \\
\hline $\mathbf{v}_{\mathbf{x z}}$ & 0.38 \\
\hline $\mathbf{G}_{\mathbf{x y}}$ & $6.5 \mathrm{GPa}$ \\
\hline $\mathbf{G}_{\mathbf{x z}}$ & \\
\hline & \\
\hline & \\
\hline & \\
\hline & \\
\hline & \\
\hline & \\
\hline & \\
\hline & \\
\hline & \\
\hline & \\
\hline & \\
\hline & \\
\hline & \\
\hline & \\
\hline & \\
\hline & \\
\hline & \\
\hline & \\
\hline & \\
\hline & \\
\hline
\end{tabular}




\begin{tabular}{|c|c|}
\hline $\mathbf{G}_{\mathbf{y z}}{ }^{*}$ & $3.73 \mathrm{GPa}$ \\
\hline $\mathbf{T}_{\mathbf{x}}$ & $2100 \mathrm{MPa}$ \\
\hline $\mathbf{T}_{\mathbf{y}}$ & $24 \mathrm{MPa}$ \\
\hline $\mathbf{T}_{\mathbf{z}}$ & $65 \mathrm{MPa}$ \\
\hline $\mathbf{C}_{\mathbf{x}}$ & $1050 \mathrm{MPa}$ \\
\hline $\mathbf{C}_{\mathbf{y}}$ & $132 \mathrm{MPa}$ \\
\hline $\mathbf{C}_{\mathbf{z}}$ & $132 \mathrm{MPa}$ \\
\hline $\mathbf{S}_{\mathbf{x}, \mathbf{y}, \mathbf{z}}$ & $75 \mathrm{MPa}$ \\
\hline
\end{tabular}

$* G=\frac{E}{2(1+v)}$

where $E$ is the Young's modulus, $v$ is the Poisson's ratio, $G$ is the shear modulus, $T$ is the tensile strength, $C$ and $S$ are the compressive strength and the shear strength respectively.
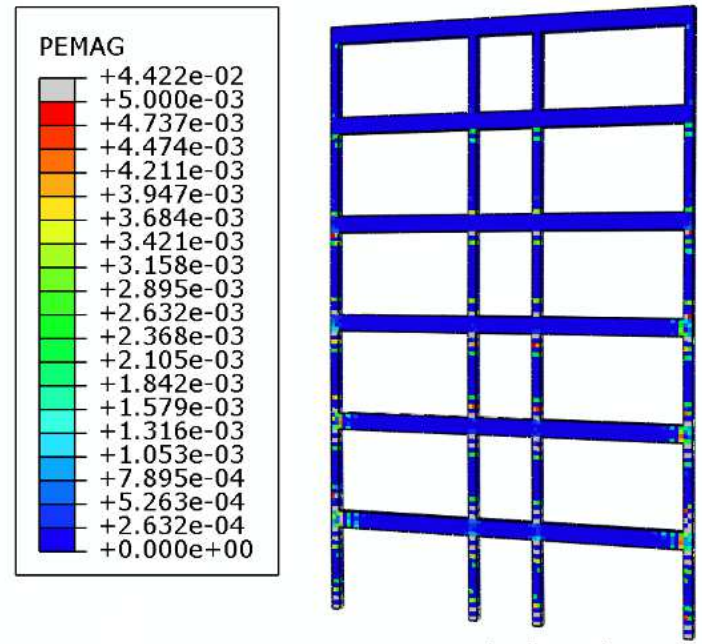

Fig. 10. The as-built structure plastic strain magnitude under Imperial Valley mainshock-aftershock

Table 5 shows the drift ratio limits according to performance levels of immediate occupancy (IO) and LS (Federal Emergency Management Agency, 2000). The IO performance level was chosen as the target performance level for 
the seismic rehabilitation. The Imperial Valley mainshock was considered to determine the required length $\left(L_{e}\right)$ and thickness (number of layers $n$ ) of the CFRP sheets. The rehabilitation strategy and drift ratio of the structure (under mainshock) before and after rehabilitation (as-built and rehabilitated models) are shown in Figs. 11(a) and 11(b), respectively. Using trial-and-error, six layers of T700 CFRP were used for the rehabilitated structure and the interstory drift ratio was less than $1 \%$ in all the stories (IO performance level).

Table 5. IO and LS performance levels drift ratio limitation of RC structures

\begin{tabular}{|c|c|c|}
\hline \multirow{2}{*}{ Structure } & \multicolumn{2}{|c|}{ Drift ratio limitation (\%) } \\
\cline { 2 - 3 } & IO & LS \\
\hline Concrete frame & 1.0 & 2.0 \\
\hline Concrete wall & 0.5 & 1.0 \\
\hline
\end{tabular}

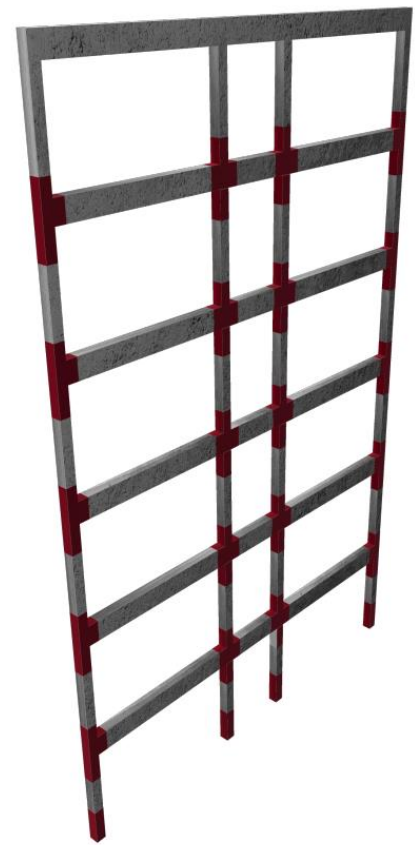

(a)

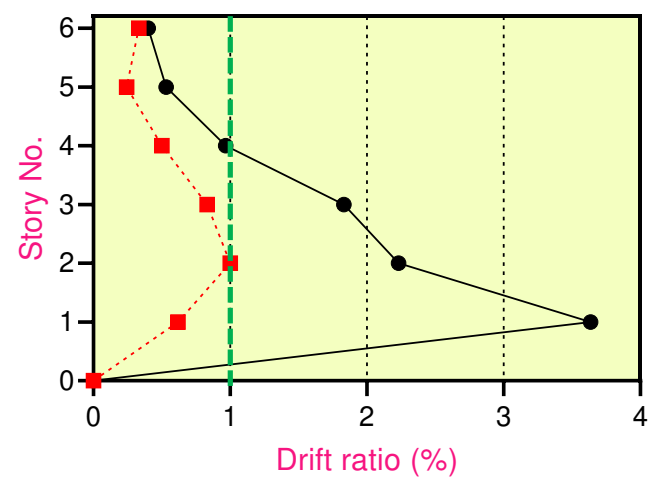

(b)

Mainshock (rehabilitated)

Fig. 11. Rehabilitation strategy: (a) place of CFRP sheets (b) drift ratio under Imperial valley ground motion 
The effective length $\left(L_{e}\right)$ of the CFRP sheets were calculated using Eq. (9), as proposed by the ACI (American Concrete Institute, 2008). The $L_{e}$ is the length required at which the FRP strain fell to zero (Fig. 12(a) and (b)), where $n$ is the number of layers (six, in this study), $E_{f}$ is the elastic modulus in $\mathrm{MPa}\left(E_{x}\right.$, in this study) and $t_{f}$ is the thickness of the FRP sheets in $\mathrm{mm}(1.02 \mathrm{~mm}$ according to Table 4$)$.

$$
L_{e(m m)}=\frac{23300}{\left(n E_{f} t_{f}\right)^{0.58}}
$$

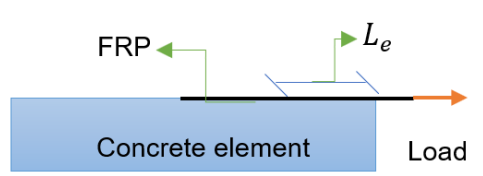

(a)

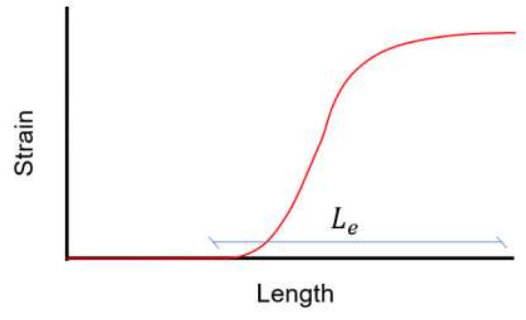

(b)

Fig.12. FRP/CFRP effective length: (a) concrete and FRP/CFRP scheme (b) strain curve through the effective length

\subsection{Seismic behavior of rehabilitated structure}

The seismic behavior of a rehabilitated structure under mainshock and mainshock-aftershock records was studied. As stated, the chosen rehabilitation strategy provides the possibility of the formation of plastic strain in the beams instead of the columns, which can substantially decrease the drift ratio and relative displacement under seismic loading. The plastic strain magnitude of the beam-column connection on the fifth story under the Imperial Valley mainshock is shown in Fig. 13. It can be seen that rehabilitation allowed the plastic strains to be transferred from the column and the beam-column connections to the beam elements, which is desirable seismic behavior (strong beam-week column concept). It can be concluded that the proposed rehabilitation strategy was sufficient.

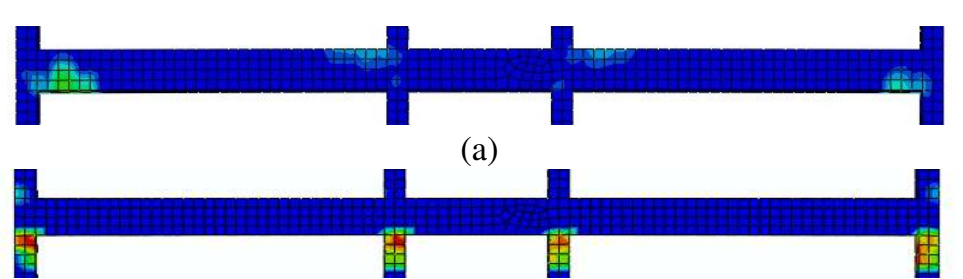

(b)

Fig. 13. Plastic strain magnitude of story five beam-column connection: (a) rehabilitated (b) as-built 
Fig. 14 and Table 6 show the drift ratios and structural seismic behavior data, respectively, for the rehabilitated structure under mainshocks and mainshock-aftershocks. The mean drift ratios of the as-built model under mainshocks and mainshock-aftershocks are shown in Fig. 13. This parameter was less than 1\% (IO performance level) under all mainshocks; therefore, the proposed rehabilitation strategy can be considered valid and sufficient.

The choice of the IO performance level for rehabilitation resulted in structural damage (plastic strain) values that were not remarkable under the mainshocks, even in the lower floors. Except for the Coalinga seismic sequence, the drift ratios did not increase under the mainshock-aftershock or seismic sequences in comparison with the mainshocks only. In this case study, the seismic sequences had little effect on the seismic behavior of the rehabilitated structure; thus, the aftershocks may not be deterministic. However, the aftershocks had an intensive effect on the seismic behavior of the as-built structures and caused an increase in relative displacement that was equal to that of the mainshocks under all selected seismic sequences.

Table 6. Seismic behavior data of the rehabilitated frame under seismic sequences

\begin{tabular}{|c|c|c|c|c|c|c|}
\hline 1 & 2 & 3 & 4 & 5 & 6 & 7 \\
\hline Event & $\begin{array}{l}\text { Top story relative } \\
\text { displacement } \\
\text { under Mainshock } \\
\text { (cm) }\end{array}$ & $\begin{array}{l}\text { Top story relative } \\
\text { displacement under } \\
\text { Mainshock- } \\
\text { aftershock }(\mathrm{cm})\end{array}$ & $\begin{array}{l}\text { Growth of } \\
3 \text { compared } \\
\text { to } 24(\%)\end{array}$ & $\begin{array}{l}\text { Mainshock- } \\
\text { aftershock top } \\
\text { drift ratio (\%) }\end{array}$ & $\begin{array}{l}\text { Story with } \\
\text { the most } \\
\text { drift ratio* }\end{array}$ & $\begin{array}{c}\text { Drift ratio } \\
\text { growth } \\
(\%)\end{array}$ \\
\hline Kozani & 11.1 & 11.1 & 0.0 & 0.65 & 2 & 0.0 \\
\hline Mammoth Lakes & 15.8 & 15.8 & 0.0 & 0.89 & 3 & 0.0 \\
\hline Cape Mendocino & 14.3 & 14.3 & 0.0 & 0.80 & 2 & 0.0 \\
\hline Imperial Valley & 10.3 & 10.3 & 0.0 & 0.58 & 2 & 0.0 \\
\hline Whittier Narrows & 8.7 & 0.87 & 0.0 & 0.49 & 2 & 0.0 \\
\hline Northridge & 7.9 & 7.9 & 0.0 & 0.44 & 2 & 0.0 \\
\hline Coalinga & 10.4 & 18.7 & 79.8 & 1.05 & 2 & 77.0 \\
\hline
\end{tabular}

$\Delta$ Growth $=\frac{\operatorname{column}(3)-\operatorname{column}(2)}{\operatorname{column}(2)}{ }^{*}$ Story with the most drift ratio under mainshock. • Drift ratio growth $(\%)$;

showing the growth of the story with the most drift ratio under mainshock-aftershock (column 6), compared to drift ratio of the same story considering solely the mainshock 


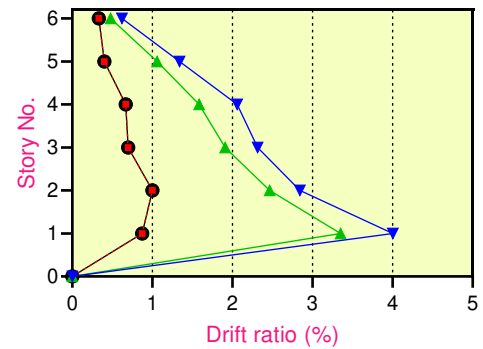

(a)

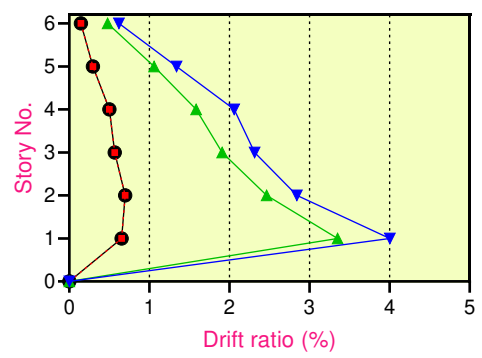

(c)

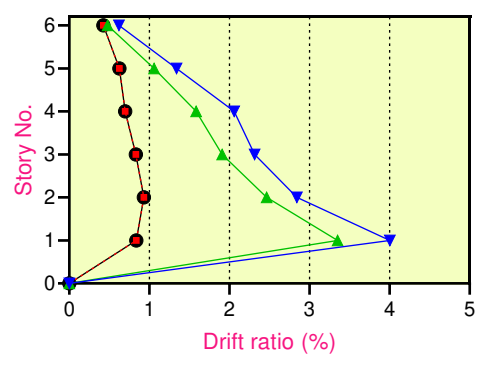

(e)

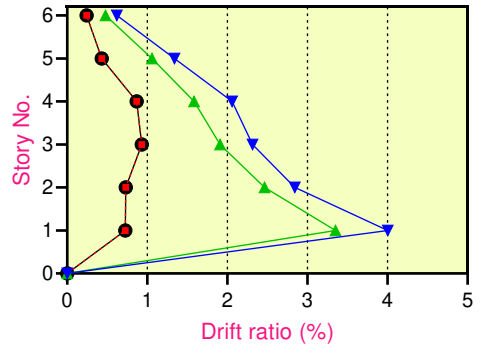

(b)

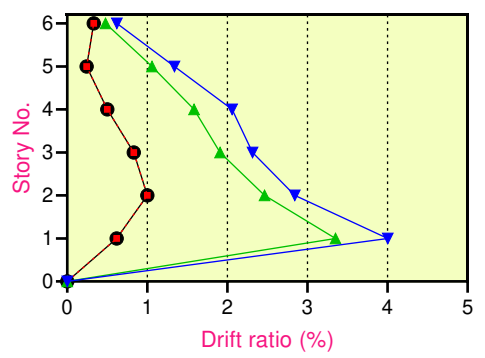

(d)

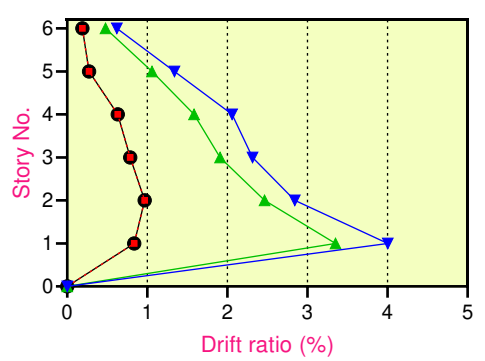

(f)

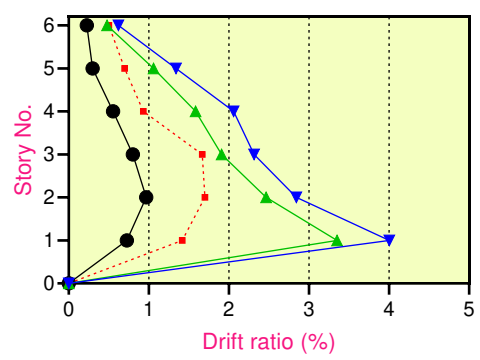

Mainshock (rehabilitated)

Mean mainshock (as-built) (g)

\section{Mainshock-aftershock (rehabilitated) \\ Mean mainshock-aftershock (as-built)}

Fig. 14. Mainshock and mainshock-aftershock drift ratios of the rehabilitated frame: (a) Kozani (b) Mammoth Lakes (c) Cape Mendocino (d) Imperial valley (e) Whittier narrows (f) Northridge (g) Coalinga

Except for the Coalinga mainshock-aftershock, the ratio of the aftershock PGA to mainshock PGA for the other seismic sequences was less than $1\left(\frac{P G A_{a}}{P G A_{m}} \leqslant 0.91\right)$. For the Coalinga seismic sequence, the ratio was 1.62 , which was remarkable and unlikely. For rehabilitated structures, the Coalinga aftershock was the only case that showed a 
growth in the damage (plastic strain), residual displacement, and drift ratio in comparison with only the mainshock. This could be the main reason behind the different seismic behaviors shown by the structures under this seismic sequence. The first-story normalized drift ratios of the rehabilitated structure under all seven mainshock-aftershocks and rate of growth compared to the mean value of the as-built structure drift ratio (same floor) are shown in Fig. 15. This figure indicates that the rehabilitated frame showed, on average, a 78\% drop in the drift ratio on the first story compared to the as-built frame. These results are related to rehabilitation based on the IO performance level. At higher structural performance levels like LS or CP, the effect of the seismic sequences could differ from that seen in this study.

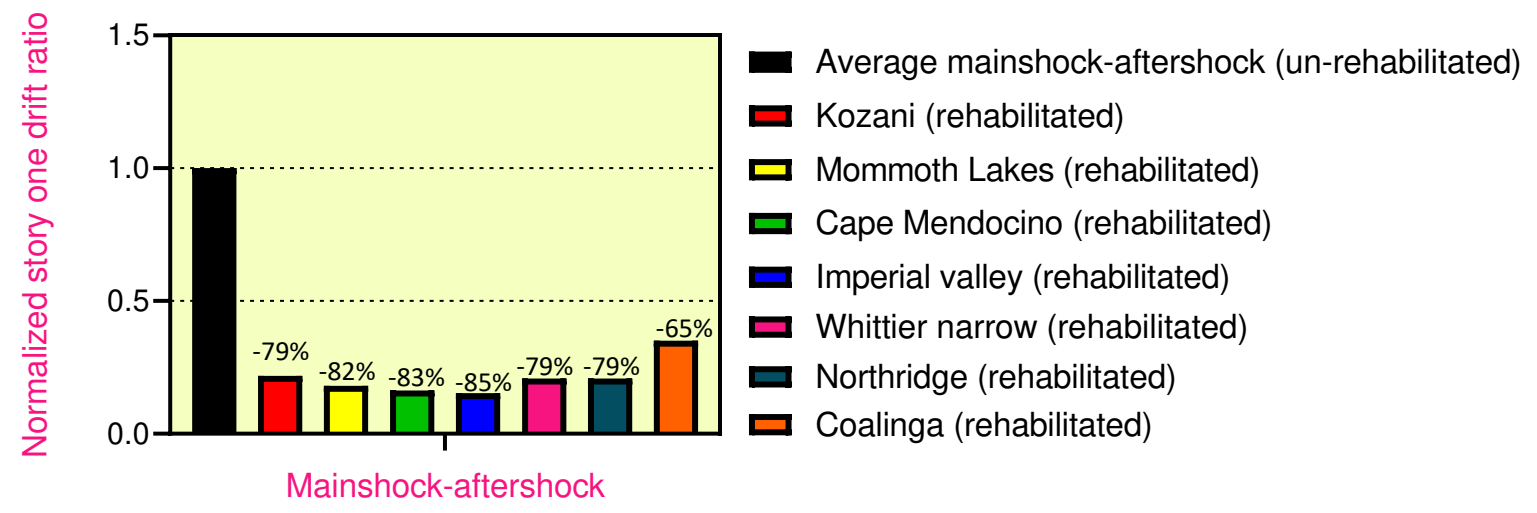

Fig. 15. Comparison between the first-story drift ratio growth of as-built and rehabilitated structures under mainshock-aftershocks

\section{Conclusions}

The realistic seismic behavior of structures under seismic sequences is of major concern in structural engineering. The effect of seismic sequences has been ignored or underestimated by seismic design codes, provisions, and the engineering community. This study focused on the seismic behavior of a multi-story RC structure. The structure was designed according to an outdated Italian provision that did not have a seismic design code using seven real scaled mainshock-aftershocks and nonlinear time-history FE analysis. A rehabilitation strategy based on beam-column bonded CFRP sheets and the IO performance level has been suggested to improve the seismic behavior of the structure. The seismic behavior of the rehabilitated structure was evaluated under the chosen seismic sequences and the results were compared to the as-built structure. The main results of this study are summarized below: 
1. The results of the analysis show that the seismic sequences had an intensive effect on the seismic behavior of the structures. On average, the top residual displacement and first-story drift ratio increased about $90 \%$ and $21 \%$, respectively, under the mainshock-aftershock compared to mainshock only.

2. The beam-column bonded CFRP rehabilitation strategy demonstrated good performance for improving the seismic behavior of the structure. The plastic strain contours indicated that the strategy transmitted plastic strains from the columns and beam-column connections to the beams, which can be considered as the strong column-weak beam concept. This sharply decreased the relative displacements of the stories.

3. According to the seismic behavior of the rehabilitated frame, unlike the as-built structure, aftershocks caused no increase in the drift ratio of any of the stories, except under the Coalinga mainshock-aftershocks. This implies that it may not be necessary to consider seismic sequences for IO-based rehabilitation under the average aftershocks. The first-story drift ratios of the rehabilitated structure showed, on average, a $78 \%$ decrease compared to the as-built frame.

4. The ratio of aftershock PGA to mainshock PGA is a determinative parameter in the seismic behavior of the structures under seismic sequences. The only aftershock that increased the drift ratio in the rehabilitated structure was the Coalinga mainshock-aftershock. The aftershock PGA to mainshock PGA for this event was 1.62, which is unusual. This ratio for the other six seismic sequences was less than 0.91 . This may be the reason for the different seismic behaviors of the rehabilitated frames under the Coalinga mainshockaftershock.

5. Overall, in rehabilitation based on the IO performance level, the level of the damage under mainshocks was slight or negligible, aftershocks (or the use of seismic sequences) caused no remarkable increase in the relative displacement, residual displacement, drift ratio, plastic strain, and so on. This indicates that the effect of the seismic sequences can be ignored in these types of rehabilitated structures.

These conclusions relate to an RC structure with rehabilitation based on the IO performance level under seven mainshock-aftershock sequences. More studies and analyses are required at different performance levels and different types of structures.

\section{Declarations}

Ethical statements (The developed method is the original effort of the authors which is not submitted or published elsewhere)

Funding (This research was not funded by any funding bodies) 
Conflict of interest/Competing interests (The Authors declare that they have no conflict of interest)

Availability of data and material (Data and material are available)

Code availability (The developed codes are available)

Plant reproducibility (Not applicable)

Clinical trials registration (Not applicable)

Gels and bolts/ Image manipulation (Not applicable)

High-risk content (Not applicable)

Acknowledgment (There is no acknowledgment)

\section{References}

Ahmadi M (2013) Analysis of rehabilitation effect on the improvement capacity of reinforced concrete beams with FEM. Procedia Engineering 54: 327-340.

Amadio C, Fragiacomo, M and Rajgelj, S (2003) The effects of repeated earthquake ground motions on the non-linear response of SDOF systems. Earthquake engineering \& structural dynamics 32-2: 291-308. doi: https://doi.org/10.1002/eqe.225.

American Concrete Institute (ACI) (2008) Guide for the design and construction of externally bonded FRP systems for strengthening concrete structures. Farmington Hills, USA.

Beer FP, Johnston R, Dewolf, J and Mazurek D (2013) Mechanics of Materials. New York, USA, McGraw-Hill.

Cabral-Fonseca S, Correia JR, Custódio J, Silva HM, Machado AM and Sousa J (2018) Durability of FRP-concrete bonded joints in structural rehabilitation: A review. International Journal of Adhesion and Adhesives 83: 153-167. doi: https://doi.org/10.1016/j.ijadhadh.2018.02.014.

Calvi GM, Magenes G and Pampanin S (2002) Relevance of beam-column joint damage and collapse in RC frame assessment. Journal of Earthquake Engineering 6-01: 75-100. doi: https://doi.org/10.1080/13632460209350433.

Carreira DJ and Chu KH (1986) Stress-strain relationship for reinforced concrete in tension. In Journal Proceedings 83-1: 21-28.

Chajlani J and Hussain A (2015) Application of FRP in concrete structures. International Journal of Engineering associates 4-8: 50-51

Dazio A and Bachmann H (2000) State of the seismic design and detailing of buildings with RC structural walls in Europe. In: Proceeding of the 12th world conference on earthquake engineering. No. 526. 
Del Rey Castillo E, Griffith M and Ingham J (2018) Seismic behavior of RC columns flexurally strengthened with FRP sheets and FRP anchors. Composite Structures 203: 382-395. doi: https://doi.org/10.1016/j.compstruct.2018.07.029.

Di Sarno L (2013) Effects of multiple earthquakes on inelastic structural response. Engineering Structures 56: 673681. doi: https://doi.org/10.1016/j.engstruct.2013.05.041.

El-Sokkary H and Galal K (2009) Analytical investigation of the seismic performance of RC frames rehabilitated using different rehabilitation techniques. Engineering structures 31-9: 1955-1966. doi: https://doi.org/10.1016/j.engstruct.2009.02.048.

Federal Emergency Management Agency (2000) Commentary for the seismic rehabilitation of buildings (FEMA356). Prestandard F. E. M. A. Washington, USA.

Ghobarah A and Abou Elfath H (2001) Rehabilitation of a reinforced concrete frame using eccentric steel bracing. Engineering structures 23-7: 745-755. doi: https://doi.org/10.1016/S0141-0296(00)00100-0.

Ghobarah A and Said A (2001) Seismic rehabilitation of beam-column joints using FRP laminates. Journal of earthquake engineering 5-01: 113-129. doi: https://doi.org/10.1080/13632460109350388.

Grazide C, Ferrier E and Michel L (2020) Rehabilitation of reinforced concrete structures using FRP and wood. Construction and Building Materials 234: 117716. doi: https://doi.org/10.1016/j.conbuildmat.2019.117716.

Hainzl S, Steacy S and Marsan, D (2010) Seismicity models based on Coulomb stress calculations. Report, Community Online Resource for Statistical Seismicity Analysis. doi: https://doi.org/10.5078/corssa-32035809. Available at http://www.corssa.org.

Hassan SA, Santulli C, Yahya MYB, Gang CL and Abu BMN (2018) The potential of biomimetics design in the development of impact resistant material. FME Transactions 46-1: 108-116. doi: https://doi.org/10.5937/fmet1801108H.

Hassan T and Rizkalla S (2002) Flexural strengthening of prestressed bridge slabs with FRP systems. PCI journal 47 1: 76-93.

Hatzivassiliou M and Hatzigeorgiou, GD (2015) Seismic sequence effects on three-dimensional reinforced concrete buildings. Soil Dynamics and Earthquake Engineering 72: 77-88. doi: https://doi.org/10.1016/j.soildyn.2015.02.005. 
Hibbitt HD and Karlsson BI (1979) Analysis of pipe whip, Report No. EPRI-NP_-1208. Hibbitt and Karlsson Inc.

Hilber HM, Hughes TJ and Taylor RL (1977) Improved numerical dissipation for time integration algorithms in structural dynamics. Earthquake Engineering \& Structural Dynamics, 5-3: 283-292. https://doi.org/10.1002/eqe.4290050306.

Hollaway LC (2014) Using fibre-reinforced polymer (FRP) composites to rehabilitate differing types of metallic infrastructure. In: Rehabilitation of Metallic Civil Infrastructure Using Fiber Reinforced Polymer (FRP) Composites. Cambridge, United Kingdom. Woodhead Publishing, pp: 323-372

İşleyen ÜK, Ghoroubi R, Mercimek Ö, Anıl Ö, Togay A and Erdem RT (2021) Effect of anchorage number and CFRP strips length on behavior of strengthened glulam timber beam for flexural loading. Advances in Structural Engineering. doi: https://doi.org/10.1177/1369433220988622.

Ji D, Wen W, Zhai C and Katsanos EI (2020) Maximum inelastic displacement of mainshock-damaged structures under succeeding aftershock. Soil Dynamics and Earthquake Engineering 136: $106248 . \quad$ doi: https://doi.org/10.1016/j.soildyn.2020.106248.

Johnson S (2006) Comparison of nonlinear finite element modelling tools for structural concrete. Urbana Champaign, University of Illinois, US.

Kurata M, Leon RT, DesRoches R and Nakashima M (2012) Steel plate shear wall with tension-bracing for seismic rehabilitation of steel frames. Journal of constructional steel research 71: 92-103. doi: https://doi.org/10.1016/j.jcsr.2011.10.026.

Li Y, Song R and Van De Lindt JW (2014) Collapse fragility of steel structures subjected to earthquake mainshockaftershock sequences. Journal of Structural Engineering 140-12: 04014095. https://doi.org/10.1061/(ASCE)ST.1943-541X.0001019.

Lie-ping YE, Qian-li MA and Zhi-wei MIAO (2010) Study on weak beam-strong column design method of RC frame structures. Engineering Mechanics 2-12: 102-113. doi: https://doi.org/10.6052/j.issn.1000-4750.2009.05.0320.

Mander JB, Priestley MJ and Park R (1988) Theoretical stress-strain model for confined concrete. Journal of structural engineering 114-8: 1804-1826. doi: https://doi.org/10.1061/(ASCE)0733-9445(1988)114:8(1804). 
Massumi, A, Sadeghi K, and Ghaedi H (2021). The effects of mainshock-aftershock in successive earthquakes on the response of RC moment-resisting frames considering the influence of the vertical seismic component. Ain Shams Engineering Journal, 12-1: 393-405 doi: https://doi.org/10.1016/j.asej.2020.04.005.

Meitz J (1998) Electrochemical rehabilitation methods for reinforced concrete structures: a state of the art report. Europe: The Institute of Materials Minerals and Mining, Europe

Moustafa A and Takewaki I (2011) Response of nonlinear single-degree-of-freedom structures to random acceleration sequences. Engineering Structures, 33-4: 1251-1258. doi: https://doi.org/10.1016/j.engstruct.2011.01.002.

Pacific Earthquake Engineering Research Centre (2011) PEER ground motion database. Available at: https://ngawest2.berkeley.edu/.

Parry RH (2004) Mohr circles, stress paths and geotechnics. CRC Press. New York, USA.

R. D. (1939) Regio Decreto Leggne. XVIII, G.U. n. 2228 (in Italian).

Ramberg W and Osgood WR (1943) Description of stress-strain curves by three parameters. NACA-TN-902, National Advisory Committee for Aeronautics, Washington, DC, United States

Ruiz-García J (2012) Mainshock-aftershock ground motion features and their influence in building's seismic response. Journal of Earthquake Engineering 16-5: 719-737. doi: https://doi.org/10.1080/13632469.2012.663154.

Ruiz-García J and Negrete-Manriquez JC (2011) Evaluation of drift demands in existing steel frames under asrecorded far-field and near-fault mainshock-aftershock seismic sequences. Engineering Structures 33: 621-634. doi: https://doi.org/10.1016/j.engstruct.2010.11.021.

Syrmakezis CA, Mavrouli OA and Antonopoulos AK (2006) Rehabilitation of hospital buildings using passive control systems. Smart Structures and Systems 2-4: 305-312. doi: https://doi.org/10.12989/sss.2006.2.4.305.

Systèmes D (2017) Getting Start with ABAQUS tutorial, ABAQUS Version 6.14. Dassault Systèmes, Providence, RI.

Toray Composite Materials America, Inc. (2020) carbon fiber products T700. Tacoma, Washington, USA.

Venture SJ (2000) State of the art report on systems performance of steel moment frames subject to earthquake ground shaking. FEMA 355C.

Wang G, Wang Y, Lu W, Yan P and Chen M (2018) Earthquake Direction Effects on Seismic Performance of Concrete Gravity Dams to Mainshock-Aftershock Sequences. Journal of Earthquake Engineering 24-7: 1-22. doi: https://doi.org/10.1080/13632469.2018.1453423. 
Wang QL, Li J, Shao YB and Zhao WJ (2016) Flexural Performances of Square Concrete Filled CFRP-Steel Tubes (S-CF-CFRP-ST). Advances in Structural Engineering 18-8: 1319-1344. doi: https://doi.org/10.1260/1369$\underline{4332.18 .8 .1319}$.

Yang D, Pan J and LiG (2010) Interstory drift ratio of building structures subjected to near-fault ground motions based on generalized drift spectral analysis. Soil Dynamics and Earthquake Engineering 30-11: 1182-1197. doi: https://doi.org/10.1016/j.soildyn.2010.04.026. 